\title{
Tracking the Success of English Language Learners within the Context of the Ontario Secondary School Literacy Test
}

\author{
Han Han and Liying Cheng (Queen's University)
}

\begin{abstract}
The study tracked 8 high school English Language Learners (ELLs) from 2 Ontario secondary schools located in small Ontario cities for 3 years and closely documented their linguistic, cognitive, and socio-cultural learning experiences. Each student was visited 2-4 times per year and face-to-face interviews were used on each visit. It was found that these students' difficulties in academic English were the major challenge to their success in their high school subject-area courses and in the Ontario Secondary School Literacy Test (OSSLT). These challenges, in turn, affected their educational goals. The findings of this study provide a rich understanding of these students' educational achievement as they concurrently learned English and their subject-area courses within the context of the OSSLT - a large-scale high-stakes literacy test.
\end{abstract}

\begin{abstract}
Résumé
Cette étude recense trois années d'expériences d'apprentissage linguistiques, cognitives et socio culturelles de huit allophones d'anglais langue seconde (ALS) issus de deux écoles secondaires situées dans des petites villes de l'Ontario. Chaque étudiant a été interviewé en face à face deux à quatre fois par an. Les résultats montrent que la difficulté majeure de ces étudiants est l'apprentissage de l'anglais académique et que cet apprentissage détermine leur succès dans tous les autres cours au niveau du lycée et au Test Provincial des Compétences Linguistiques (TPCL) de l'Ontario. Ce défi affecte également leurs objectifs éducatifs. Les résultats de cette étude montrent non seulement les performances éducatives de ces étudiants en ALS mais aussi dans leurs autres cours dans le cadre du TPCL, un test à enjeux élevés.
\end{abstract}

Since the 1990s, a fast-rising number of high school students 'whose first language is a language other than English or is a variety of English that is significantly different from the variety used for instruction in Ontario schools' (Ministry of Education, 2007b, p. 8) have arrived in Ontario schools every year. They are referred to as English Language Learners (ELLs) ${ }^{5}$ (Ministry of Education, 2007a; 2007b). Some of these students are new immigrants who have come with their parents seeking a better education and life in Canada, and some are international students on a student visa who need to graduate from a Canadian high school before pursuing higher education in Canada. These immigrant and international students are mostly academically competent ELLs and set high educational goals for their academic success (Roessingh \& Field, 2000). They need, however, to develop their English literacy skills at the same

\footnotetext{
5 'English language learners (ELLs)' are used in this study as defined in Ontario Ministry of Education documents since 2007. Prior to 2007, these students were referred to as 'English-as-a-second language (ESL) students'. As this study was a three-year study, both terms are retained and ESL and ELL students refer to the same group of students in Ontario schools.
} 
time as they meet the academic requirements for high school graduation and university entrance.

Alongside the increase in ELL student population are amplified educational expectations and assessment (Cheng, Klinger, \& Zheng, 2007). In North America, large-scale high-stakes testing is used to measure and ensure student competency and provide system accountability (Firestone, Mayrowetz, \& Fairman, 1998; Ryan, 2002). In Canada, Alberta high school students have to take the Grade 9 Achievement Test and Grade 12 Diploma Examinations; Ontario high school students have to write the Grade 10 Ontario Secondary School Literacy Test (OSSLT). Large-scale high-stakes testing such as the OSSLT has brought more and new challenges to students (Luce-Kapler \& Klinger, 2005), particularly those taking these tests in a language other than their first language (Cheng \& Stroud, 2002; Sider, 2003). Cheng et al (2007) examined two years' OSSLT test performance of two groups of students: (a) those whose first language was English or who had been in the Canadian school system since they were born, and (b) ELLs who recently came to the Canadian school system and used English as a second language. This study identified specific areas of challenges in literacy development faced by the English Language Learners in taking the OSSLT. As well, the study provided suggestions for further research and targeted instruction for ELLs in Canadian high schools.

Recent studies have revealed the challenging reality of ELLs in Canadian high schools. The longitudinal research by Watt and Roessingh $(1994,2001)$ reported that $74 \%$ of immigrant students dropped out of secondary education in 1989 in one Alberta urban school, and this dropout rate remained unchanged over a decade. Derwing, DeCorby, Ichikiwa, and Jamieson (1999) reported in their study of ELL students that only 54\% of high school ELLs completed high school compared to a $70 \%$ completion rate for all students in Alberta. As evidenced by low success and high deferral rates of ESL students on the OSSLT (see Education Quality and Accountability Office, 2003, 2007a, 2007b, 2007c, and 2009-10), many of these students are struggling as they attempt to obtain fundamental English literacy skills and succeed in their schooling. A number of studies on high school ELL students in Canada (e.g., Cheng et al., 2007; Derwing et al., 1999; Watt \& Roessingh, 1994, 2001) have reported quantifiable outcomes that illustrate the problematic situations of this group of students and have identified the factors that facilitate and/or impede their academic success. Nevertheless, fewer studies have documented these students' academic experiences in the context of large-scale provincial testing. Roessingh (2004) suggested that researchers and educators conduct studies "with anecdotal and other qualitative data that will provide a fuller understanding of ESL learners' 
educational achievement and success" (p. 630). Also, as most studies of ELL students were focused on the ELLs in large urban areas (Brown, 2004; Karanja, 2007), little attention has been directed to the situation of high school ELLs in smaller cities where the immigrant population is relatively small but quickly increasing in recent years. This tracking study thus documented these ELL students' learning experience in Ontario schools in relation to the OSSLT.

\section{CHALLENGES FACED BY ENGLISH LANGUAGE LEARNERS}

Research has indicated that ESL students have to face multiple challenges in North American educational institutions (e.g., August \& Hakuta, 1997; Bialystok, 1985; Chamot \& O’Malley, 1994; Cummins, 2000; Herrera \& Murry, 2005; McNeil, 2000). These challenges fall into three main categories: cognitive academic language development, large-scale high-stakes assessments, and sociocultural aspects of learning.

\section{Cognitive Academic Language Challenges}

ESL students need to develop the academic language necessary to perform well in the subject-area domains (Chamot \& O'Malley, 1994; Cummins, 2000; Herrera \& Murry, 2005). Solomon and Rhodes (1995) defined academic language as "the language of lecture and of textbooks" (p. 9). They said: "[Academic language] is filled with expectations of prior knowledge and background and cultural uniformity. The vocabulary can be very technical and is topic-specific" (p. 9). Cummins (2000) described the construct of cognitive academic language proficiency (CALP): it involves the capacities to understand and produce language in an abstract and context-reduced situation and to participate in cognitively complex linguistic and academic tasks (pp. 67-69). Chamot and O'Malley (1994) detailed the challenges of academic language for ELL students in high school subject domains. For example, the academic language in social studies includes unfamiliar political and cultural concepts, expository discourse styles, and sentences in textbooks with multiple embeddings. The domain of science is even more demanding of the academic language skills and capacities of students who are required to propose and defend hypotheses or arguments by using complex linguistic structures and advanced reasoning.

Using academic language requires a high level of cognitive control over language. Bialystok (1985) presented a model of the cognitive dimensions of language processing, which includes conversation, reading/writing, and metalinguistic skills. Conversation, embedded in a rich context of relationship, requires a low level of cognitive control. Reading and writing are context 
reduced and more related to the cognitive function of language; they therefore require more analysis of knowledge, a higher level of abstraction, and the ability to use language as a cognitive organizer. Metalinguistic skills require the highest level of analyzed knowledge, abstraction, and cognitive control. Herrera and Murry (2005) believed that academic language proficiency is cognitively challenging for ESL students when they communicate in such cognitively demanding environments as science, social studies, mathematics, and language arts classrooms.

\section{Challenges of Large-Scale High-Stakes Assessments}

According to Herrera and Murry (2005), ELL students encounter academic challenges related to academic policy, curriculum, and instruction. In academic policy, large-scale high-stakes assessments make up the greatest challenge to ELL students. For example, in the United States, high-stakes assessments derive from educational and national reform agendas such as the "No Child Left Behind" initiative. Garcia (2000) observed that educational policies were implicitly linked to testing policies, that is, students of limited English proficiency were expected to acquire English, study and learn subject matter in English, and take state-mandated assessments as soon as possible (p. 3). Garcia pointed out that the policies had the most egregious consequences for middle or high school ELL students who spoke limited English and did not have effective language programs for support. These reforms drive efforts to increase accountability, but often at the expense of ELL students who are limited in English proficiency. Regarding ELL students taking the state- or provincemandated assessments, some researchers (e.g., August \& Hakuta, 1997; Cummins, 2000) questioned the validity and appropriateness of such tests to ELL students. August and Hakuta (1997) said: "The central problem in assessing English language learners is their limited ability to perform on a test administered in English. Assessments based on translation into a second language have questionable validity" (p. 274). Cummins (2000) pointed out that, as a minimal period of five years is required for ELLs to catch up academically with their native-English-speaking peers, educators need to consider when is the appropriate time for ELL students to take such tests and what accommodations should be made to ensure the validity of those tests.

\section{Sociocultural Challenges}

Herrera and Murry (2005) listed a series of sociocultural challenges that secondary ELL students have further to face: adjusting to a new country, adapting to a new educational system, and coping with the school's culture. 
Sometimes, the culture of the school conveys subtle and incomprehensible messages; for example, not open to diversity, low tolerance for accented and broken English, and few instructional accommodations for ELLs at grade levels. Derwing et al. (1999) reported the stigma attached to ELLs; for example, they were laughed at for their accent by other students and their knowledge and ability were degraded. Herrera and Murry (2005) explained that ELL students' prior knowledge and ability in content areas are mistakenly assumed to be limited because they "generally exhibit some level of limited English proficiency" (p. 37). Sociocultural challenges can lead to anxiety, anger, and frustration in ELL students, which, in turn, reduce their performance in school and affect their academic success. Some ELL students become reluctant to participate in learning projects or to produce for fear of ridicule (p. 16). Their withdrawal can prevent them from being "cognitively stretched toward new and grade-level-appropriate learning in the content areas" (p. 37).

In sum, to achieve academic success, ELLs have to cope with the challenges derived from linguistic, cognitive, academic, and socio-cultural aspects as well as from large-scale high-stakes assessments. The above literature served as a strong rationale for the current tracking study of ELLs' academic success within the context of the OSSLT. The primary research question for this study was: What experiences and challenges have the ELLs faced in their English language learning, in their subject area courses, and in passing the OSSLT?

\section{METHODOLOGY}

\section{The Ontario Secondary School Literacy Test (OSSLT)}

The OSSLT was developed by the Education Quality and Accountability Office (EQAO) in Ontario, Canada. Given the large geographic size of Ontario and its variability in urban structures (urban, suburban, and rural locations), education is expected to meet the needs of a diverse student population. The purpose of the OSSLT is to "determine whether a student has the literacy (reading and writing) skills required to meet the standard for understanding reading selections and communicating in a variety of writing forms expected by The Ontario Curriculum across all subjects up to the end of Grade 9" (EQAO, 2007a). Students at Grade 10 are eligible to write the test. Since its trial run in 2000, the OSSLT has been administrated on a yearly basis to all Ontario students (including two administrations in 2002).

The OSSLT is a province-wide testing program that requires successful completion as a graduation requirement for an Ontario Secondary School Diploma (OSSD) (EQAO, 2007a). All students working toward an OSSD in public and private Ontario schools must complete the OSSLT. Those who have 
not been successful on the literacy test twice can take an Ontario Secondary School Literacy Course (OSSLC) at Grade 12. Students can choose to defer writing the test to a subsequent administration. For many English language learners, this means an extra year in the high school. The test consists of a series of reading and writing tasks. Students who "[are] enrolled in an ESL or ELD ${ }^{6}$ course at level 1, 2, 3, 4 or ESL Level $5^{7}$ (Bridge to English)" are allowed to have double time to complete the test (EQAO, 2007c).

\section{Participants}

In the fall of 2005, 11 high school ELLs were invited to participate in the tracking study. These students were from two high schools located in two small cities in Ontario respectively with a population of 49,000 and 117,000 . Scott College (S.C.) ${ }^{8}$ was a private boarding school, and half of its students were from outside Canada. Royal High School (R.H.) was a public school, the majority of whose students were from the local community; this school is also an ESLdesignated school and houses the largest ESL student population in the city. Owing to the high mobility of new residents in Canada, 3 students moved with their family out of the cities and thus withdrew from the study at the end of the first year; 8 ELLs stayed throughout the study.

The study's 8 participants were all from Asian countries on immigrant or student visas (see Table 1). Six of them were new arrivals to Canada in the fall 2005; 1 had been to an Ontario public high school for a year, dropped out, and attended a private ESL program before attending the current high school; and 1 had attended Grades 5 and 6 in an Ontario elementary school, returned to her home country for $2 \frac{1}{2}$ years, and then came back to attend her current high school. At the time of the study in 2005, 5 students were in Grade 10, 2 in Grade 9, and 1 in Grade 11. Before coming to Canada, they had learned English in their home schools for various lengths of time. Based on their entrance English proficiency ${ }^{9}$, they were placed in the ESL courses at different levels from 1-5. They were taking the ESL courses and other subject-area courses simultaneously at the time of the study.

\begin{tabular}{|l|c|c|c|c|c|c|}
\hline \multirow{2}{*}{ Origin } & First & Learning & \multicolumn{3}{|c|}{ Study in Canadian High School } \\
\cline { 4 - 6 } & & Language & English at & & Grade & English Level \\
\cline { 4 - 6 } & & & & & &
\end{tabular}

\footnotetext{
${ }^{6}$ ELD program means English literacy development program.

${ }^{7}$ There are 5 levels in the ESL program and 4 levels in the English literacy development (ELD) program (Ministry of Education, 2007a).

8 All names of schools and students in this paper are pseudonyms for the purpose of confidentiality.

${ }^{9}$ The participating schools have an informal teacher assessment system for their new ESL students.
} 


\begin{tabular}{|l|c|c|c|c|c|c|c|c|}
\hline & (L1) & $\begin{array}{c}\text { Home } \\
\text { School } \\
\text { (years })\end{array}$ & School & $\begin{array}{c}\text { Year 1 } \\
2005 / 6\end{array}$ & $\begin{array}{c}\text { Year 2 } \\
2006 / 7\end{array}$ & $\begin{array}{c}\text { Year 1 } \\
2005 / 6\end{array}$ & $\begin{array}{c}\text { Year 2 } \\
2006 / 7\end{array}$ \\
\hline Annie & Korea & Korean & 3 & R.H. & 9 & 10 & ESL-2 & ESL-3 \\
\hline Enyung & Korea & Korean & 4 & S. C. & 10 & 11 & ESL-2 & ESL-5 \\
\hline Yuriko & Japan & Japanese & 3 & S. C. & 10 & 11 & ESL-2 & ESL-5 \\
\hline Fu Yu & China & $\begin{array}{c}\text { Chinese/ } \\
\text { Cantonese }\end{array}$ & 4 & R.H. & 9 & 10 & ESL-3 & ESL-5 \\
\hline Megan & Taiwan & Chinese & $5-6$ & S.C. & 10 & 11 & ESL-5 & GE 11 \\
\hline Cheryl & China & Chinese & 6 & R.H. & 10 & 11 & ESL-5 & GE 10 \\
\hline Edward & $\begin{array}{l}\text { Hong } \\
\text { Kong }\end{array}$ & $\begin{array}{c}\text { Chinese/ } \\
\text { Cantonese }\end{array}$ & $7-8$ & S.C. & 10 & 12 & ESL-5 & GE 12 \\
\hline Kuan-Hui & Korea & Korean & $7-8$ & S.C. & 11 & 12 & ESL-5 & GE 11 \\
\hline
\end{tabular}

Table 1 Profile of the Participants

Note. GE 10 means Grade 10 English, GE 11 means Grade 11 English, GE 12 means Grade 12 English.

\section{Tracking Methods}

The rationale for this tracking study was to follow these individual students closely in order to understand their learning experiences within the context of the OSSLT over a period of time (Fox, 2004) and on a case-to-case basis (Brown \& Rogers, 2002). The relationship between students' perceptions of the test and their literacy development in schools was of particular interest to the study. The interrelationship between the OSSLT and the aspects of their academic success, including their choices of and achievement in subject-area courses, reading and writing activities in school, and their educational goals were closely examined. To achieve the above purposes, a series of informal interview formats were used to track these students over the years, including face-to-face interviews. Different questions were asked at each time, yet the questions were all centered on the above theme of their learning experiences, their perceptions of the test, selection of courses, strategy for learning, and plans for the future. For example, the researchers told a personal story about their own learning history as a way to connect with these students at the first interview and as an invitation for them to talk about themselves and their prior learning (see a sample interview protocol in the Appendix).

\section{Data collection and analysis}

Each of the students was visited on their school campus two to four times per year. In addition, close contact with these students was kept via e-mail and through their counselors, teachers, and/or vice-principal. All the data were digitally recorded and transcribed, and observations of the participants' progress in their use of English were also observed at each visit.

Data analysis was framed with interim and inductive analysis (McMillan \& Schumacher, 2001; Patton, 2002). Interim analysis started from the beginning of 
the study, so that the emerging topics and recurring patterns were identified to refine and inform the follow-up interview questions and observations. In the inductive analysis process, data were coded into segments based on the topics, and themes were elicited from the interim analysis; then, similar segments were clustered and identified for emerging patterns (Patton, 2002). Patterns and the relationships were identified among the themes as shown in Figure 1.

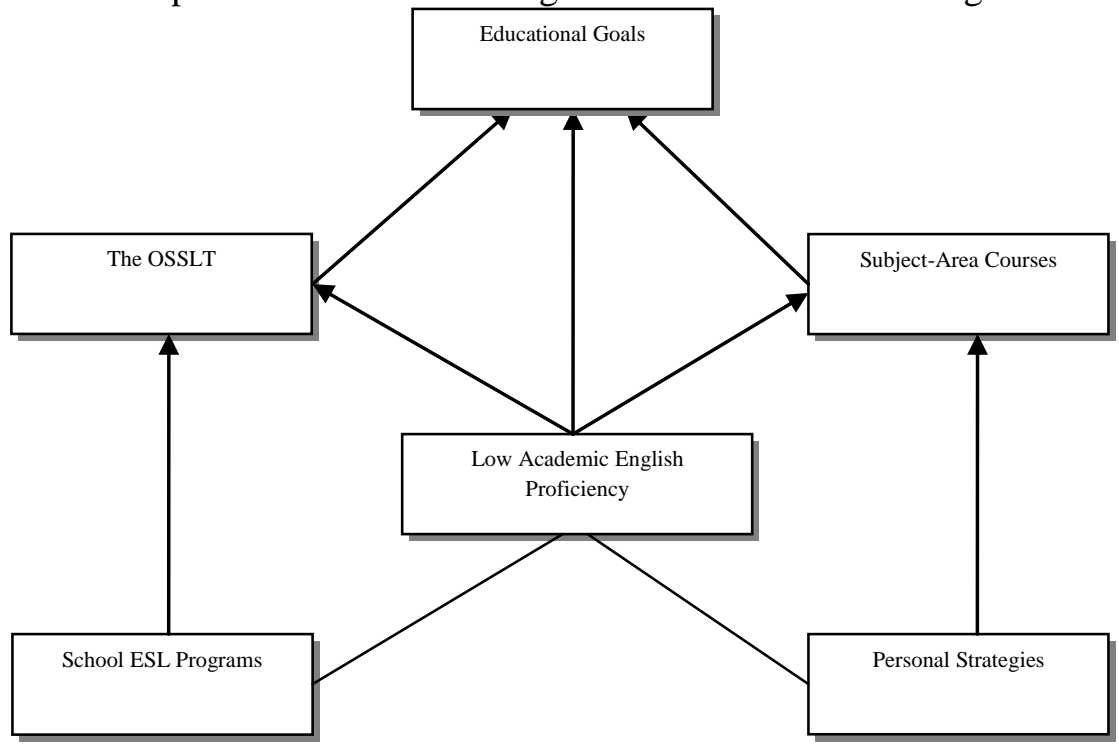

Figure 1 Relationship among the Themes of Data Analysis

\section{FINDINGS AND INTERPRETATIONS}

Throughout the 3 years of the tracking study, low academic English proficiency (in centre Figure 1) was a recurrent theme experienced by the 8 ELL students. This central theme was related to a variety of challenges faced by these students in the OSSLT (left top in Figure 1) and in subject-area courses (right top in Figure 1). To them, academic success meant graduating from high school with acceptable enough academic results that they could enter their desired fields of learning in Canadian universities as indicated by their educational goals (top centre in Figure 1). While the school ESL programs (left bottom in Figure 1) were intended to support these students to develop English proficiency and pass the OSSLT, these students also needed to resort to various personal strategies (right bottom in Figure 1) to succeed in the subject-area courses. Figure 1 shows the complex nature of these ELL students' challenges and success over the 3 years of their high schooling within the context of the Ontario Secondary School 
Literacy Test, derived from the study data. The findings will be unpacked below accordingly.

\section{Students' educational goals}

1. Course selection and field of study in universities

These eight ESL students all aimed at attending universities in Canada and were highly motivated to achieve their goals. They had specific plans about what field of study to engage in, what kinds of universities to go to, and what career paths to take in the future. For example, Kuang-Hui (see Table 1 for Profile of Participants) decided to study engineering and management at the University of Toronto; other students were interested in studying business, commerce, economics, and management. To realize their dreams, they have to take the relevant high school courses that would lead to successful admission to their desired fields of learning, and they need to keep acceptable academic results to be accepted to their target universities. In reality, however, their selection of courses was confined by their insufficient English competence. As a result, the courses they finally chose might not take them toward their fields of interest in their desired universities. To a great extent, their English proficiency, not their interests, decided their subject-area courses, which, in turn, affected their future educational goals.

Edward had planned to study commerce or business management at the University of Toronto. In his two years of high school, he struggled with English and barely passed the OSSLT and Grade 12 English. To fast track towards graduation, he avoided courses that required high demands of English reading and writing. Instead, he took three Grade 12 math courses to earn sufficient credits for university entrance. It turned out that he did not get into University of Toronto to study business, but he was accepted to study mathematics at another Ontario university.

\section{Graduation time}

The insufficient language competence also affected some ESL students' plans for graduation. Both Kuang-Hui and Cheryl chose to stay one more year in Grade 12. After he passed the OSSLT in Grade 11, Kuang-Hui did not rush his study pace so he could do well in his courses and allowed himself time to continue to improve his English competence. He was already in Grade 12 in the fall 2006, but he needed one more year to take a few more courses, so he could have an opportunity to improve his marks. He worked towards a better chance of being accepted into his desired university to study engineering in 2008. Sheryl merged into the Grade 11 mainstream classrooms, but she was always a step behind her 
course schedule. "Because I just finished the ESL, I have to start with Grade 10 English," she explained. "That's what ESL students usually take when they finish the ESL course." Her goal was to study business at the University of Toronto or the University of Western Ontario. "They are the best if you are going into business," she said. "I actually plan to stay two years in Grade 12. University will be more challenging for us right now."

Edward and Annie did not want to postpone their graduation time. Edward finished three year of courses in two years and rushed to graduate. Annie planned to graduate at the end of Grade 12 as most of her classmates would do, but her deferral of the literacy test would definitely delay her graduation. She would soon move into Grade 11, yet she has not finished her ESL courses. "I have to take regular English [language courses] for Grade 9, 10, 11, and 12. I haven't taken [any]," she said, with anxiety in her voice. It seemed almost impossible for her to complete the OSSLT and all the mandatory courses within the next two years in Grades 11 and 12. She probably would have to graduate at least one year later than her classmates.

\section{Challenges of the OSSLT}

The EQAO data indicates the low passing and high deferral rates of ELL students in the successive seven years from 2002-2008 (see EQAO, 2008, p. 14). The challenges of the test are also evident to the ELL students under study. Of the 8 ELL students from the two schools, 2 students deferred the test, and 4 students failed the test the first time; only 2 students achieved a marginal pass the first time test they took the test in 2006 (see Table 2).

\begin{tabular}{|c|c|c|c|}
\hline & \multicolumn{3}{|l|}{ OSSLT } \\
\hline & Result & Challenge & Impact \\
\hline Annie & Deferred first test & Very difficult & Nervous about the test \\
\hline Enyung & Failed first test & Reading, writing & $\begin{array}{l}\text { Negative about the test; not confident to pass the } \\
\text { second one }\end{array}$ \\
\hline Yuriko & Failed both tests & $\begin{array}{l}\text { Reading, writing, } \\
\text { vocabulary }\end{array}$ & Not confident to pass the test \\
\hline $\mathrm{Fu} \mathrm{Yu}$ & Failed first test & Vocabulary & Sad at the result \\
\hline Megan & Failed first test & $\begin{array}{l}\text { Vocabulary, time } \\
\text { constraint }\end{array}$ & $\begin{array}{l}\text { Not confident to pass the second test as a regular } \\
\text { student }\end{array}$ \\
\hline Cheryl & Deferred first test & $\begin{array}{l}\text { Grammar, time } \\
\text { constraint }\end{array}$ & $\begin{array}{l}\text { Not confident to pass the test as a regular } \\
\text { student }\end{array}$ \\
\hline Edward & Passed first test & Vocabulary & $\begin{array}{l}\text { Relieved; able to have more course options and } \\
\text { move forward }\end{array}$ \\
\hline Kuan-Hui & Passed first test & $\begin{array}{l}\text { Reading, writing, } \\
\text { vocabulary }\end{array}$ & $\begin{array}{l}\text { Relieved; able to have more course options and } \\
\text { move forward }\end{array}$ \\
\hline
\end{tabular}

Table 2 Challenge and Impact of the OSSLT 


\section{Deferral of the OSSLT}

Annie and Cheryl deferred their first-time test for different reasons. Annie started from ESL Level 2 at Grade 9 and moved to the level 3 at Grade 10. In her school, ESL students are not recommended to take the literacy test until they reach Level 4 or above. "I think I will take it [next year]," Annie said. She perceived that the OSSLT would be very difficult for her, and she expected to receive some test preparation from her school. Cheryl did not write the test in the 2006 administration at Grade 10 either, although she was about to complete the ESL Level 5 course. She did not feel ready for the test: "I chose not to take the test because I need more time to prepare for it," she explained. "I choose to do it this year [2007]. I guess [I'm] a little better than last year because time can take you through things so that you can get better." She went up to Grade 11 and merged into a mainstreamed classroom, but still found the OSSLT challenging. With grade-level courses and many assignments to handle, she could hardly set aside time to practice for the test. "We have lots of reading and assignments to finish, so we don't have much time in class for the test. They [teachers] just give us the [OSSLT] booklet for us to do at home, like that," she said. She had no idea how the reading and writing in her Grade 11 English literature course were related to the reading and writing tasks that would appear in the literacy test. She merely did a sample test, "just [to] see how many questions I could get right in the fixed time." She was not sure whether she would pass the test or not. "I can't say I feel confident with it, because I'm afraid I'm not going to finish it. I usually write the test slow."

\section{Failure in the test}

Of the 6 ELL students who wrote the test in March 2006, only 2 were marginally successful. Four failed the test and had to rewrite it in 2007, and 1 failed the 2007 test. This student left this school in the fall of 2007 and went to Alberta to attend a high school there. These 6 ELL students, successful or unsuccessful the first time they took the test, felt that both the reading and writing components were very difficult. The biggest challenge from the test was vocabulary. Some of them had not completed the reading or writing tasks because they did not know the words in the test questions, the multiple-choice statements, and the topics for the writing tasks. Fu Yu said:

I think everything is not hard if you understand the words. Those multiple choices, because you don't understand the vocabulary, so that's a problem. They ask the questions like 'what does this mean in other way,' they gave you a list of words and you have to pick 
one. If you don't know the words, you can't pick [a correct one]. It's by luck, choose by luck. (FY, June 15, 2007)

Right after walking out of the testing room, Yuriko knew she had not passed the test. "I did not understand the question[s]," she said. "Also, it's harder [for me] to write clear answers in English." Megan, who was quite fluent in oral English, also felt frustrated after the test. She did not know the word "invention" in the title of a writing task. "I just don't know the meaning of that word, so I don't know how to write about it." Edward and Kuang-Hui, the 2 students who had passed the 2006 literacy test, also recalled that vocabulary made the reading tasks difficult. "It [Reading] was difficult, like there were a lot of vocabulary that I didn't know. 'Interrupt,' that kind of words, it's hard to read," said Kuang-Hui. Edward had the same feeling, "The reading, the last reading [was difficult], because lots of vocabulary I don't know."

Writing was another challenge for these ESL students not only because of vocabulary, but also because they were expected to write different genres in English. The OSSLT writing component consists of four writing tasks: a summary, a series of paragraphs expressing an opinion, a news report, and an information paragraph. Students are required to organize ideas, write complete sentences, and use correct spelling, grammar, punctuation, and writing skills. Although these were basic skills for the mainstream Grade 10 students, these literacy skills were still challenging for the ESL students who were not yet competent in linguistic and academic use of English and had limited exposure to and knowledge of English writing genres.

Organizing ideas and putting them in the appropriate genre were beyond these ESL students' academic English competence at the time they took the test. $\mathrm{Fu} \mathrm{Yu}$ thought that the news report was difficult to write because he had to create an event based on a picture and a headline. Not familiar with the genre of an English news report, the students organized ideas by addressing the cues that were embedded in the instruction of the task, such as "who," "what," "when," "where," and "how." Yuriko was frustrated with the long writing task of the opinion piece. "Longer [writing] is harder because you need to write more sentences on one topic." The students' language difficulties impeded a full manifestation of their existing knowledge. So they just wrote what their limited vocabulary and grammatical knowledge allowed them, regardless of the genres and styles.

In sum, the literacy test was not a pleasant experience for these ESL students. Annie and Cheryl, who had deferred the test, felt worried and nervous about writing the test in the near future. To Fu Yu, Megan, Yuriko and Enyoung, failing the test the first time they took it made them feel sad and even hurt their 
confidence that they could do well in the 2007 administration. The unsuccessful experience of the OSSLT became a burden on their graduation. Edward and Kuang-Hui felt relieved at passing the test although it was barely a pass. "It [passing the test] encouraged me to take another optional course and not have to take the literacy course," Edward said. He and Kuang-Hui could move forward and take other mandatory and credit courses toward graduation.

\section{Challenges of subject-area courses}

The challenges that these ESL students experienced with the OSSLT were also reflected in their learning of subject-area courses. Their language difficulties in subject-area courses (see Table 3) were consistent with the language problems they identified in the OSSLT (see Table 2). In addition, a lack of cultural and background knowledge in some subject domains also made learning more challenging.

\begin{tabular}{|l|l|l|}
\hline & \multicolumn{1}{|c|}{ Difficult Courses } & \multicolumn{1}{c|}{ Difficulties in Grade Level Courses } \\
\hline Annie & ESL, math & Language, terms/terminology, subject knowledge \\
\hline Enyung & $\begin{array}{l}\text { Most courses, esp. } \\
\text { Chemistry, American } \\
\text { History (dropped) }\end{array}$ & Any course demanding in vocabulary and language \\
\hline Yuriko & $\begin{array}{l}\text { Most courses, esp. } \\
\text { Psychology, Science }\end{array}$ & $\begin{array}{l}\text { Any course demanding in language, vocabulary, } \\
\text { terms/terminology }\end{array}$ \\
\hline Fu Yu & ESL, Geography, Science & Grammar, vocabulary, cultural knowledge \\
\hline Megan & PE, Science, GE 11 & Vocabulary, terms/terminology, language, \\
\hline Cheryl & History & Reading, writing, background knowledge \\
\hline Edward & ESL, PE & Vocabulary \\
\hline Kuan-Hui & GE 11; American history & Vocabulary; cultural and background knowledge \\
\hline
\end{tabular}

Table 3: Difficult Courses and Difficulties in Subject Area Courses

Note. PE is physical education.

\section{1. "It's just the vocabulary"}

For these ELL students, difficult courses had higher demands in English. Although "difficult courses" was a concept relative to the development of their English proficiency, vocabulary was always a problem at each stage of their study. Edward thought that Physical Education (PE) was difficult because the rules of a particular sport and the course had "more vocabulary than math." To $\mathrm{Fu} \mathrm{Yu}$, the ESL Level 4 course was the most challenging of all the courses he took in Grade 10. "You learn whole new things, grammar, and you read the novel and literature, like Shakespeare," he said. "The language of Shakespeare's time is very difficult, not easy to understand." Megan and Enyoung took vocabulary as the biggest obstacle to their learning. "The first thing is vocabulary," said Megan. 
"With vocabulary we can write more [complicated] things in our paragraph or our story."

The problem of vocabulary became more apparent when the students advanced to more subject-area courses and/or after they joined the mainstream classrooms. Yuriko felt that every course was challenging in terms of English language demands, and she was behind in all the courses she took. "Lots of reading, writing, and extensive vocabulary, and dictionaries do not always have the terms [definitions]," she complained. Megan was mainstreamed into a regular classroom at Grade 11, but she was struggling with Chemistry.

I don't understand words. I keep checking dictionary. We can understand them in Chinese or Korean, the terms for chemical elements. But it's in English; English is different. We don't know the names of the group [elements], and we have to read the names for homework. So we didn't know what the teacher talked about [in class], just like one minute for homework, and finished! She never talked about that [any more]. I was just like: What was that? It's just vocabulary, not subject. (Mg, Sept. 28, 2006)

Because of the subject vocabulary, these ESL students had to spend more time dealing with words and terms and working out the meaning of each subject. Enyoung said that she had to do "a lot of work" on each subject.

\section{2. "Need more English skills and background knowledge"}

These ESL students found that some courses were challenging because they required a high level of academic English and the background knowledge relevant to the subject areas. Looking back at the past two years of learning, Kuang-Hui said, "The most challenging course was American History because it needed more English skills." By English skills, he meant academic writing skills to write towards the required writing genre for the history course. Cheryl thought that writing for the Canadian History course was more difficult than writing for the English course. "For the English course, you can base [it] on your own opinions, like things you have experience with," she explained. "But [for] history, you have to base [it] on the knowledge you learned in history, not your own opinions or anything. So it's more difficult because you also have to know things in history." To complete a writing assignment, she had to spend more time reading reference books to make up for her lack of knowledge of historical, social, and cultural events in Canadian history, the knowledge that her Canadianborn peers might be quite familiar with. "If I have enough time, I should be able to understand all things. Just the time," she sighed.

Kuang-Hui and Cheryl had a hard time with the History courses, but their effort paid off as they passed those courses. Enyoung took American History in the fall 
2006, but she had to drop it. She struggled with both in academic writing and the background knowledge of American history. "I don't know anything about America," she said. "I dropped it, American History."

\section{ESL programs and personal strategies for academic success}

The ELL students in this study discussed the usefulness of the ESL programs in supporting their learning, and they described the strategies they had used to succeed in the OSSLT and subject-area courses in their high schools. One extra area of challenges discussed by these students was the isolation they felt from the mainstream community.

\section{Pros and cons of the ESL programs}

The students mentioned that the ESL courses helped them learn English during their initial study in Canada. They usually had 3 hours of ESL class every school day, totaling 15 hours each week. Yuriko and Enyoung said that the ESL courses were tailored to their "English levels." $\mathrm{Fu} \mathrm{Yu}$ and Cheryl thought "the ESL course is helping in grammar." Annie desperately relied on the ESL program: "I need ESL," she said, believing that ESL courses would prepare her to succeed in the OSSLT and her subject-area courses.

However, some of the students in this study thought that the ESL courses were not connected with their subject-area courses. Yuriko and Enyoung believed that the ESL courses "focus[ed] on English mostly, not taking [anything from] regular courses such as chemistry and geography [into consideration]." Megan further pointed out that the vocabulary learned in ESL class was not up to the vocabulary level in other subject domains: "ESL just focuses on English, not on other courses. So the teacher can teach you like the vocabulary or something about the [ESL] course, [but] you [still] can't really understand other courses." These students had basic English skills or even fluent conversational competence, but their academic language was still far behind the Englishspeaking students. According to them, there was still a steep learning curve from the ESL courses to the mainstream courses.

\section{Strategies for success}

These ELLs were found to use various strategies to improve their English and succeed in their course work. Cheryl and $\mathrm{Fu} \mathrm{Yu}$ tried to enlarge their vocabulary by reading novels after class. Cheryl also obtained help from her subject-area teachers: "I asked him [a teacher] to proofread my writing, like journals and projects." Kuang-Hui made good use of the tutorials in school: "We have extra help twice a week," he said. "At that time I usually meet my American History 
teacher to get [more] information." Annie, Yuriko, and Megan tried to solve the problem of vocabulary by memorizing the new words in math, chemistry, and science. Megan deliberately made friends with other ESL students whose first language was different from hers so that she could keep talking in English.

Most of the ELLs, however, mentioned that they got help from classmates or friends who had the same linguistic background. When having problems with their school work, $\mathrm{Fu} \mathrm{Yu}$ and Edward would ask those Chinese friends on campus who spoke Cantonese or Mandarin: "I would ask my friends," said Edward. "I would look at their notes after class and figure out the [subject] terms." $\mathrm{Fu} \mathrm{Yu}$ claimed that staying with Chinese students and talking in Cantonese or Mandarin helped him. "We all borrow notes from each other," he said. Enyoung asked her Korean friends to translate the class notes. Yuriko also tried to catch up with the class by all means: "I ask my Japanese friends, and I understand the part [that they explained] and memorize it. I look for any kind [of] books, the same thing in Japanese books." Relying on their first languages to learn some subject area courses seemed to delay their progress in learning academic English; however, it helped them understand the subject content.

\section{Isolation from the mainstream community}

During the interviews, these ELL students expressed eagerness to be capable of "communicating with English speakers" and to make friends with their Canadian classmates; they knew that making friends with Canadian students would be helpful for improving their English and other subject-area courses. It was noticeable, however, that these ELLs had hardly any native-English-speaking friends in their schools. Megan, Yuriko and Enyoung felt that some students did not have enough patience with them regarding their English. "Some people can not understand us [because] we have [a] lot of accent," said Megan. "Some people are not patient, like they ask something [and] you can't understand, they say 'Never mind' and they go away. That's like hurt us." Such unpleasant experiences discouraged the ELLs from joining group projects and having interactions with their Canadian peers. Yuriko told us that she was in a project group, but she quit after 15 minutes of the discussion. "I had to escape," she said. "I couldn't understand what they [were] talking about; they talked too fast." Edward also said that he never participated in any after-class group discussions because he could not follow his native-English-speaking peers' conversations.

Both Kuang-Hui and $\mathrm{Fu} \mathrm{Yu}$ believed that making friends with Canadian students was one of the most challenging experiences in Canadian schools. "In such a multicultural school, people have different ways of thinking and expressing. It's hard to make new friends," said Kuang-Hui. Fu Yu elaborated 
that "Canadian students talk in their own terms, which can't be found in [any] dictionary." Although the narrow thinking of other students to the ELL students' accented English was partially responsible for these ELL students' isolation from the mainstream group, insufficient English proficiency made it harder for the ELL students to get involved in the community and benefit from the rich linguistic and academic resources in the school context.

\section{DISCUSSION}

\section{The triple challenges faced by the high school ELLs}

It is recognized in the research community that ESL high school students face dual challenges in their three to four years of high school in English-speaking contexts - that is, learning the English language and studying the mandated academic subjects (see Roessingh \& Field, 2000). In this study, we point out the third challenge - the challenge of the large-scale high-stakes testing such as the OSSLT that is tied to the graduation requirements, extra courses and extra time in high school. According to the OSSLT Curriculum Connections (Education Quality and Accountability Office, 2003), the literacy test not only evaluates the reading and writing skills that students gain up to the end of Grade 9, but it also assesses the accumulative knowledge and skills that students have acquired through literacy education from Grade 1 to Grade 9. It is extremely difficult for ELL students to reach such literacy competence in English merely through a couple of years of ESL courses in which they acquire the basic English reading, writing, and communicating skills. In fact, according to Cummins (2000), ELL students will take much longer to reach academic literacy. To succeed in the literacy test - an additional requirement and in their academic courses, ELLs must learn at a faster pace and demonstrate stronger learning abilities to make up what they have missed before studying in Canadian schools. They also need to understand that it will take time for them to catch up with their Canadian peers. To achieve such academic success, they have to make much more effort than their native-English-speaking classmates and it may mean extra years in high school. This in turn means more tuition fees and more financial pressure on their families. The study's results indicate that some students pushed themselves to complete and had to revise their educational goals.

It is essential that the school administrations, subject-area course teachers, and the mainstream students understand the challenges and difficulties that ESL students have to overcome in order to be successful. The tough learning experiences of these 8 ELL students in this study indicate that the subject-domain vocabulary can be a real hurdle to their academic success. The subject-area course teachers need to understand that, although these ELL students have 
acquired certain English skills and proficiency, they continue to work in their second language. However, most subject-area course teachers have not had sufficient training in supporting students who are limited in academic English proficiency yet who have to take cognitively challenging courses in mainstream classrooms. A good understanding of the mainstreamed ELLs would help the subject-area course teachers adjust their instructional approaches and provide more effective support to the ELL students to overcome their linguistic, academic, and cognitive challenges.

\section{The OSSLT and ELL students' academic success}

Successful completion of the OSSLT is an important step to graduation or academic success. Nevertheless, preparing for the OSSLT did not necessarily enhance the ELLs' academic English proficiency to the extent that they can fully comprehend and cope with their academic demanding courses. This is obvious from the findings of this study. For those students who passed the OSSLT, the challenges of academic English still existed in their study of subject-area courses, as confirmed by Edward: "Passing the literacy test does not mean anything [to my study]." But to those who deferred or failed the test, the OSSLT was a barrier that blocked their access to further course selection and to graduation. What is more, the high rate of failure only made their schooling even more challenging and frustrating.

\section{Rethinking 'academic success'}

Among the current studies on high school ESL students' academic success, the term 'academic success' is defined as successful completion of academic courses at the high school level (Roessingh, 1999) and/or successful completion of "the academic literature course(s) required for university registration" (Roessingh \& Field, 2000, p. 28). Such a definition of academic success, however, does not take into account the ELL students' desired fields of learning and their educational goals. In this study, Edward did not reach his educational goal to study business and commerce. The admission criteria to his chosen university's School of Business include a relatively higher English language requirement than the admission requirement for some other disciplines, such as mathematics. Edward had fast tracked towards graduation with a marginal pass in the OSSLT and Grade 12 English, which, in turn, put him in a 'disadvantaged' position to compete for admission to the School of Business. His "academic success"successful completion of high school and university entrance - did not bring him closer to his desired goal in higher education. From his case, there are reasons of concerns about the situation that Annie, Yuriko, and Enyoung would have run 
into when they came to compete for admission to their chosen fields of business, commerce, and management in the coming year, considering their difficulties in academic English and English-demanding courses. From the ELL students' narratives and learning experiences, their conception of academic success is closely related to their development of academic English proficiency in high school within a given time frame. It is important for school administrators and teachers to know that academic success, therefore, will not be fully realized unless it is understood as solid progress in academic English proficiency and qualitative performance in subject-area courses, which lead the ELLs to better chances for acceptance into and success in their desired fields of learning in higher education.

\section{CONCLUSION}

The influx of immigrant and visa students at Canadian high schools has increased and, as a result, has changed the classroom demographics. Many of these high school ELL students want to pursue a university education. Within three to four years, they study to attain the academic requirements for high school graduation and university admission (Roessingh \& Field, 2000). They carry triple challenges of improving their English proficiency, doing well in subject area courses, and succeeding in the large scale high-stakes test like the OSSLT. In addition to the academic pressure, they have to handle the challenges derived from cultural and communicative frustration. For schools hosting ELLs, it is important to increase administrators' and teachers' awareness of such challenges and to develop effective ESL programs to improve ELLs' academic English competence. It is also critical that subject-area teachers provide both language and content support to ELL students with continuous development of academic language even after they are mainstreamed into the grade-level classroom. To contribute to the overall Canadian educational success, ELL students' academic success should be a shared goal of provincial ministries of education, school boards and schools, ESL teachers, and subject-area teachers. It is imperative to build effective programs and supportive learning communities in our high school system to support ELL students to achieve their academic success.

\section{References}

August, D., \& Hukuta, K. (Eds.) (1997). Improving schooling for language-minority children: A research agenda. Washington, DC: National Academy Press.

Bialystok, E. (1985). The compatibility of teaching and learning strategies. Applied Linguistics, 6(3), $255-262$.

Brown, J. D., \& Rogers, T. S. (2002). Doing second language research. Oxford: Oxford University Press.

Brown, R. (2004). TDSB secondary student success indicators, 2003-2004. Issued by the Organizational Development Department, Research and Information Services. Toronto. 
Chamot, A. U., \& O’Malley, J. M. (1994). The CALLA handbook: Implementing the cognitive academic language learning approach. Reading, MA: Addison-Wesley.

Cheng, L., Klinger, D., and Zheng, Y. (2007). The challenges of the Ontario Secondary School Literacy Test for second language students. Language Testing, 24(2), 185-208.

Cheng, L., \& Stroud, R. (2002, May). What has happened with the introduction of the Ontario provincial Grade 10 Literacy Test? A look at one high school. Paper presented at the Canadian Society for Study of Education, Toronto.

Cummins, J. (2000). Language, power and pedagogy: Bilingual children caught in the crossfire. Clevedon, UK: Multilingual Matters.

Derwing, T. M., DeCorby, E., Ichikawa, J., \& Jamieson, K. (1999). Some factors that affect the success of ESL high school students. The Canadian Modern Language Review, 55(4), 532-547.

Education Quality and Accountability Office (EQAO). (2003). OSSLT curriculum connections. Retrieved November 3, 2007, from http://assessment.wrdsb.on.ca/pdfs/Curric Connections.pdf

Education Quality and Accountability Office (EQAO). (2007a). Ontario Secondary School Literacy Test, 20062007. Retrieved October 29, 2007, from http://www.eqao.com/eqao/pdf e/07/07P017e.pdf

Education Quality and Accountability Office. (2007b). Results by student status over time: ESL/ELD learners. Retrieved October 29, 2007, from http://www.eqao.com/pdf e/07/07PO17.pdf.

Education Quality and Accountability Office. (2007c). Special provisions for ESL or ELD learners. Retrieved October 29, 2007, from http://www.eqao.com/pdf e/07/07P17.pdf.

Education Quality and Accountability Office. (2008). Results by student status over time: English language learners. Retrieved October 13, 2008, from http://www.eqao.com/pdf e/08/CPRR Xe 0608 web.pdf.

Education Quality and Accountability Office. (2009-10). Ontario Secondary School Literacy Test (OSSLT), 2009-2010. Retrieved December 16, 2010, from http://www.eqao.com/pdf_e/10/SummaryResultsStrategiesTeachers_OSSLT2010.pdf

Firestone, W., Mayrowetz, D., \& Fairman, J. (1998). Performance-based assessment and instructional change: The effects of testing in Maine and Maryland. Educational Evaluation and Policy Analysis, 20(2), 95-113.

Fox, J. (2004). Test decisions over time: Tracking validity. Language Testing, 21(4), 437-465.

Garcia, G. N. (2000). Lessons from research: What is the length of time it takes limited English proficiency students to acquire English and succeed in an all-English classroom? National Clearinghouse for Bilingual Education, 5, 1-14.

Herrera, S. G., \& Murry, K. G. (2005). Mastering ESL and bilingual methods: Differentiated instruction for culturally and linguistically diverse (CLD) students. New York: Pearson Education, Inc.

Karanja, L. (2007). English learning experiences of immigrant students in high schools in a small city. TESL Canada Journal, 24(2), 23-41.

Luce-Kapler, R., \& Klinger, D. (2005). Uneasy writing: The defining moments of high-stakes literacy testing. Assessing Writing, 10, 157-173.

McMillan, J., \& Schumacher, S. (2001). Research in education: A conceptual introduction (4 ${ }^{\text {th }}$ ed.). New York: Longman.

McNeil, L. (2000). Contradictions of school reform: Educational costs of standardized testing. New York: Routledge.

Ministry of Education. (2007a). English as a second language and English literacy development: The Ontario curriculum grade 9 to 12. Toronto, ON: Queen's Printer for Toronto.

Ministry of Education. (2007b). English Language Learners: ESL and ELD programs and services. Toronto, ON: Queen's Printer for Toronto.

Patton, M. (2002). Qualitative research \& evaluation methods ( $3^{\text {rd }}$ ed.). Thousand Oaks, CA: Sage.

Roessingh, H. (1999). Adjunct support for high school ESL learners in mainstream English classes: Ensuring success. TESL Canada Journal, 17(1), 72-85.

Roessingh, H. (2004). Effective high school ESL programs: A synthesis and meta-analysis. The Canadian Modern Language Review, 60(5), 611-636.

Roessingh, H., \& Field, D. (2000). Time, timing, timetabling: Critical elements of successful graduation of high school ESL learners. TESL Canada Journal, 18(1), 17-31. 
Ryan, K. (2002). Assessment validation in the context of high-stakes assessment. Educational measurement: Issues and practice, 21(1), 7-15.

Sider, S. (2003). The experience of ESL teachers with the Ontario Secondary School Literacy Test: Implications for foreign students studying in Canada. Paper presented at Canadian Society for Study of Education, Halifax.

Solomon, J., \& Rhodes, N. (1995). Conceptualizing academic language (Research Report \#15). Santa Cruz, CA: The National Center for Research on Cultural Diversity and Second Language Learning.

Watt, D., \& Roessingh, H. (1994). ESL drop-out: The myth of educational equity. The Alberta Journal of Educational Research, 40(3), 283-296.

Watt, D., \& Roessingh, H. (2001). The dynamics of ESL dropout: Plus ca change! The Canadian Modern Language Review, 58(2), 203-222.

\section{ACKNOWLEDGEMENT}

The authors acknowledge the support from the Social Sciences and Humanities Research Council (SSHRC) of Canada. Thanks also go to the eight ELL students who participated in the tracking study during their busy school year and to the administrators and teachers from their schools for their collaboration and support.

Han Han is a Research Associate in the Centre for Studies in Primary Care, Department of Family Medicine, Queen's University. Her research interests include curriculum studies, second language teacher development and second language literacy. She can be reached at han.han@dfu.queensu.ca.

Liying Cheng a Professor in the Faculty of Education at Queen's University where her research focus includes language assessments, second language acquisition and language teacher education. She can be reached at liying.cheng@queensu.ca. 